\title{
Case Study to Determine the Causes of Fire in Agriculture
}

\author{
Marianna Tomašková*,1, Darina Matisková ${ }^{2}$, Michaela Balážiková1 \\ ${ }^{1}$ Department of Production Safety and Quality, Technical University of Kosice, Košice, 040 01, Slovakia \\ ${ }^{2}$ Department of Industrial Engineering and Informatics, Faculty of Production Technologies in Prešov, Košice, 04001 Slovakia
}

\section{A R T I C L E I N F O}

\section{Article history:}

Received: 18 June, 2020

Accepted: 11 August, 2020

Online: 08 September, 2020

Keywords:

Fire analysis in Agriculture

Machine risks

Man - machine - environment

system

\begin{abstract}
A B S T R A C T
The aim of this paper is to identify a critical link in the man - machine - environment system in the case of an adverse event, such as a hay baling fire, based on a comprehensive risk assessment method. The rate of spread of fires in agriculture depends on meteorological conditions, with large areas affected and potentially endangering the surrounding buildings, facilities. Access to fires is difficult and can extend to forests. Water is often lacking at the scene of a fire, which should be extinguished, and water sources are usually located over long distances. The paper addressed a specific example using a comprehensive method. The process of risk assessment in the work process was determined by the following steps: assessment of the overall risk of the work equipment, assessment of environmental impact, assessment of the person's ability to manage risk, calculation of the resulting risk value, comparison of calculated risk value and acceptability of risk value, proposal of measures. The result of the analysis was the finding that the primary cause of the fire is the environment, i.e. high ambient temperature. The critical element in hay baling work system is the work environment. The risk ratio was estimated at 5.78. The level of risk was low due to the rapid intervention of the human factor. Based on the results, the technical measures mentioned in the paper were proposed to the operator. The paper found that maintenance of the machine is important for protection against agricultural fires, where the human factor plays an important role in the man - machine - environment system.
\end{abstract}

\section{Introduction}

Agriculture is one of the most dangerous sectors in terms of accidents at work. There is an accident rate for employees in agriculture without fatalities 1.7 times higher than the average and accident rate with fatalities is three times higher than the average [1].

Fires pose a risk of destroying the environment and human lives [2]. The causes of fire in agricultural machinery are various. The literature [3] lists several possibilities in which a fire may occur: e.g. in the engine, in the bearings, brakes. Maintenance of these machines is an important fire protection.

Maintenance activities in agriculture are very diverse, including the following activities:

- maintenance and repair of machinery, equipment and vehicles,

- maintenance of farmyards and buildings,

- maintenance of silos, tanks, manure tanks and grain tanks,

"Corresponding Author: Marianna Tomašková, marianna.tomaskova@tuke.sk www.astesj.com

https://dx.doi.org/10.25046/aj050502
- maintenance of electrical installations,

- maintenance of drainage and irrigation systems,

- maintenance of paved and unpaved roads.

The following hazards can be identified during these maintenance activities:

- mechanical hazards when working with maintenance machinery, for example crushing, connecting and highpressure injection means,

- electrical risks,

- thermal risks,

- chemical risks associated with the use of hazardous substances during maintenance or maintenance of equipment containing hazardous substances,

- risk of explosion or fire or during maintenance,

- biological risks in the maintenance of contaminated equipment,

- ergonomic risks, e.g. incorrect construction of tools,

- work activities in enclosed spaces. 
Wheeled machines, mostly agricultural, are responsible for up to $50 \%$ of fatal accidents worldwide. Work safety, work activities and these machines are very important.

For the detection of fires in agriculture, there are almost no studies aimed at identifying the causes in harvesters, respectively. tractors with accessories. Studies to date [4] in which the authors investigated more than 4,000 fires in combines and tractors. They gained access to machines to conduct a detailed study for 265 cases. The authors concluded that $74 \%$ of fires occurred in the engine area (e.g. surface heating, flue gas outlet and electrical components). They found that the material that began to burn was crop residues, followed by fuel and oil residues [5].

The tractor is used as a means of accessing hard-to-reach areas, driving and towing connected equipment. For carrying out various agricultural activities, such as harvesting, plowing, fertilizing. Although there are innovative machines and processing methods, there are still risks, such as machine fires, due to low investment in maintenance or machine replacement [6].

To reduce the occurrence of fire, it is possible to apply various systems, e.g. FOGMAKER TM system, which is highly innovative but not available for small businesses. The contribution of the presented paper is to evaluate the risk of hay baling by a complex method in which the bearing was damaged. The press is one of the most risky machines in agriculture. Fires and malfunctions are caused by bearing failure or overheated machine parts.

\section{Material and Methods}

\subsection{Fire safety measures for machines from the Baler company}

During harvesting season, fires on agricultural machinery or buildings occur more frequently than in the off-season.

The task of the balers is to continuously pick up the wilted or more often dry material (hay, straw) from the summarized rows, press it and tie it into bales [1,6].

In most cases, presses with variable chambers pose the greatest risk of fire. The fault is most often caused by tensioning and control rollers, which are responsible for the operation of packaging belts [2-7].

Bearings called seasonal bearings used in such machines must be replaced each year before the start of the summer season. Overheated bearings can come into contact with straw, hay and the right hot surface can initiate a negative phenomenon. Before starting work with the press in the field, it is recommended to switch on the press for 5-10 minutes and then check the bearings [7].

Due to the presence of dry straw or hay in the baling chamber, which has a flash point of approximately $300^{\circ} \mathrm{C}$ depending on the moisture content, as well as rubber bands on the rollers, which are constantly in contact with the hot surface and can heat up during normal operation, they create all the conditions for a fire. The operator of the machine is often able to watch the process only from a mirror.

With such an amount of dry material (straw, hay) it is difficult to extinguish the fire in 1-2 minutes so that the fire does not spread further. In such fires, the greatest chance of rescuing the tractor in the event of a quick uncoupling of the baler [8].
Another important parameter is the parallel guidance of the forming strips at the same distance. If these belts are not lowered in parallel, sooner or later their friction will lead to a fire. Gear bearings also deserve attention even if they are less exposed to direct contact with straw, but accidental dust and other contaminants can also cause a flammable substance to ignite when the bearings are overheated due to wear [9]. There is illustrated in Fig. 1 the baler machine KRONE Big Pack and the same kind of machine damaged after a fire accident is in Fig. 2.

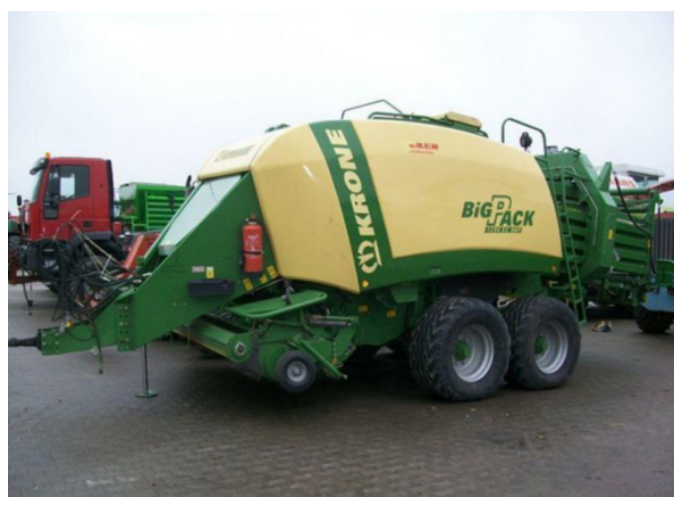

Figure 1: KRONE Big Pack 1290XCHDP

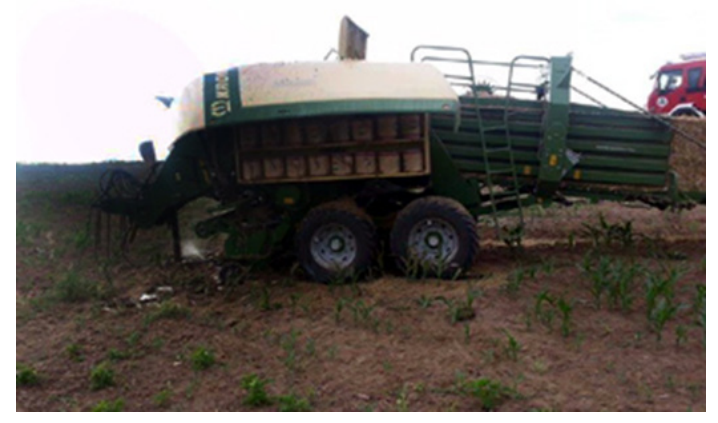

Figure 2: Damaged Big Pack 750 after the fire accident [10]

\subsection{Risk analysis of the selected equipment}

A comprehensive workplace risk assessment method was used to assess the risks of the selected press [8-10].

The risk assessment at work was performed using a comprehensive method of risk assessment at the workplace [11]. Common practice in small and medium-sized enterprises requires time-saving methods, which, however, presuppose knowledge of the actual state of the monitored technology. The method developed by the international team of the Security Section (represented by France, Germany, Italy and the Czech Republic) can be satisfactory in this respect. The method is based on the knowledge that an injury occurs in most cases for several reasons. The work is performed in the system man $(\mathrm{P})$ - machine $(\mathrm{M})$ environment (U) and the level of safety depends on all three elements - parameters. These elements are assessed individually by this method, by appropriately assigning a point method and defining an acceptable risk. The method is mainly suitable for immediate risk assessment in order to apply immediate, noncomplex measures. The record is kept in the form of a questionnaire [12]. The values in the risk assessment were determined by direct consultation with the tractor driver. 
Profession: tractor driver

Equipment under assessment: baler

Description of job: The damaged bearing got stuck and the action of frictional force led to the accumulation of heat, which passes into the chamber of the press and subsequently a machine fire occurred.

Description of the work procedure: After observing the fire, the tractor driver stopped the tractor and the press brake, switched off the drives and exits the tractor, then extinguishes the fire with the help of fire extinguishers. Table 1 shows the risk assessment of machinery, namely the baler.

Table 1: Risk assessment of the equipment

\begin{tabular}{|c|c|c|c|c|}
\hline \multicolumn{2}{|c|}{ Risk element - M } & Rating & Label & Range \\
\cline { 1 - 2 } assessment & Equipment (baler) risk & 7 & $1-10$ \\
\hline $\begin{array}{c}\text { Identification } \\
\text { of possible } \\
\text { damages } \\
\text { consequences } \\
\text { (Burns) }\end{array}$ & $\mathrm{S}$ & $\mathrm{Ex}$ & $\mathbf{1 . 5}$ & $1-2$ \\
\hline $\begin{array}{c}\text { Danger } \\
\text { exposure }\end{array}$ & $\begin{array}{c}\text { Frequently } \\
\text { repeated } \\
\text { exposure }\end{array}$ & $\mathrm{Wa}$ & $\mathbf{1 . 5}$ & $\begin{array}{c}\text { Severe } \\
1.5\end{array}$ \\
\hline $\begin{array}{c}\text { Probability } \\
\text { of a } \\
\text { dangerous } \\
\text { situation }\end{array}$ & Central & $\mathrm{Ve}$ & $\mathbf{0 . 5}$ & $0.5-1$ \\
\hline $\begin{array}{c}\text { Possibility of } \\
\text { prevention }\end{array}$ & United & & & \\
\hline
\end{tabular}

$$
\begin{aligned}
& M=S x E x \times \text { Wax Ve } \\
& \boldsymbol{M}=\mathbf{5 . 2 5}
\end{aligned}
$$

The resulting risk level of machinery from the range $(0.25-30)$ is 5.25 .

Table 2 shows the risk assessment of the working environment.

Table 2: Environmental impact

\begin{tabular}{|c|c|c|c|c|}
\hline \multicolumn{2}{|c|}{$\begin{array}{c}\text { Environmental impact - } \\
\mathbf{U}\end{array}$} & Result & Label & Range \\
\hline $\begin{array}{c}\text { Work } \\
\text { organization } \\
\text { area }\end{array}$ & $\begin{array}{c}\text { On one } \\
\text { level }\end{array}$ & $\mathrm{Ua}$ & $\mathbf{0 . 6}$ & $0.5-1$ \\
\hline $\begin{array}{c}\text { Work } \\
\text { environment }\end{array}$ & Dust, heat & $\mathrm{Ub}$ & $\mathbf{0 . 6}$ & $\begin{array}{c}0.3- \\
0.6\end{array}$ \\
\hline Other loads & $\begin{array}{c}\text { A narrow } \\
\text { space }\end{array}$ & $\mathrm{Uc}$ & $\mathbf{0 . 4}$ & $\begin{array}{c}0.2- \\
0.4\end{array}$ \\
\hline & $U=U a+U b+U c$ \\
$U=1.6$
\end{tabular}

The resulting risk level of the working environment from the range (1-2) is 1.6 . Here it can be seen that the risk of the working environment is higher. Table 3 shows the risk assessment of the human factor.

The resulting risk factor for human factor from the range (15 0 ) is 15 . Here it can be seen that the risk of human factor failure is low.

\begin{tabular}{|c|c|c|c|c|}
\hline \multicolumn{2}{|c|}{$\begin{array}{c}\text { Ability of the operator to } \\
\text { handle the risk-P }\end{array}$} & Rating & Label & Range \\
\hline $\begin{array}{c}\text { Person } \\
\text { classification }\end{array}$ & \begin{tabular}{|c|} 
An \\
educated \\
person with \\
experience
\end{tabular} & Q & 10 & $10-0$ \\
\hline $\begin{array}{l}\text { Psychological } \\
\text { factors }\end{array}$ & $\begin{array}{c}\text { Appropriate } \\
\text { mental } \\
\text { ability } \\
\end{array}$ & $\varphi$ & 3 & $3-0$ \\
\hline $\begin{array}{c}\text { Work } \\
\text { organization }\end{array}$ & \begin{tabular}{|c|} 
The \\
prescribed \\
workflow is \\
not always \\
used
\end{tabular} & $\mathrm{O}$ & 2 & $5-0$ \\
\hline
\end{tabular}

Table 3: Operator competence manage the risk

The resulting degree of risk of the human-machineenvironment work system is determined by the following relation (4).

$$
\begin{aligned}
& R=M \times U-P \times(M / 30) \\
& R=5.25 \times 1.6-15 \times(5.25 / 30) \\
& \underline{\boldsymbol{R}=\mathbf{5 . 7 8}}
\end{aligned}
$$

The resulting level of risk when baling straw using a tractor with an attachment is low, but the method found that the cause of the fire was the working environment, i.e. high ambient temperature.

Based on the risk assessment, the following measures have been proposed to the operator. The first place of protection against agricultural fires is the maintenance of the machine.

\subsection{Proposal of risk minimization measures}

This phenomenon can be prevented by inserting a bearing temperature measuring device into a combine or press, thus reducing the risk of fire. Bearing-mounted temperature sensors transmit data to the device, where they are displayed. On the screen it is possible to monitor the bearing temperatures during operation can avoid the risk. It is possible to set the temperature limit, if a bearing with a red circle is signalled, then the temperature has exceeded the value that is set [13].

These bearing thermometers are also designed to detect the temperature of the bearing housing. The tip of the sensor is designed to make the best contact with the measured surface. The sensor should be placed directly in the hole. The clamping ring together with the spring ensures clamping on the surface so that information about the condition of the bearing is available. In the 
event of overheating by the sensor signal, the machine can be stopped to prevent damage.

Parameters of the given sensor are:

- maximum ring diameter: $8 \mathrm{~mm}$,

- measuring range: from $-25^{\circ} \mathrm{C}$ to $+250^{\circ} \mathrm{C}$,

- wire length: $2 \mathrm{~m}$.

The innovative baler process already has this system built in, but older types are only cleaned mechanically. The hydraulically driven turbo fan, Fig. 3 and Fig. 4, system protects the knotters from pollution and reduces the risk of dust explosion [14].

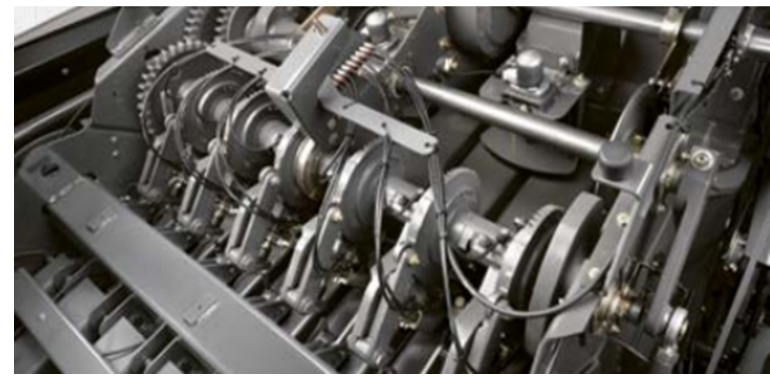

Figure 3: The hydraulically driven turbo fan system protects the knotters from pollution, a strong air flow with speed $140 \mathrm{~km} / \mathrm{h}$. [14]

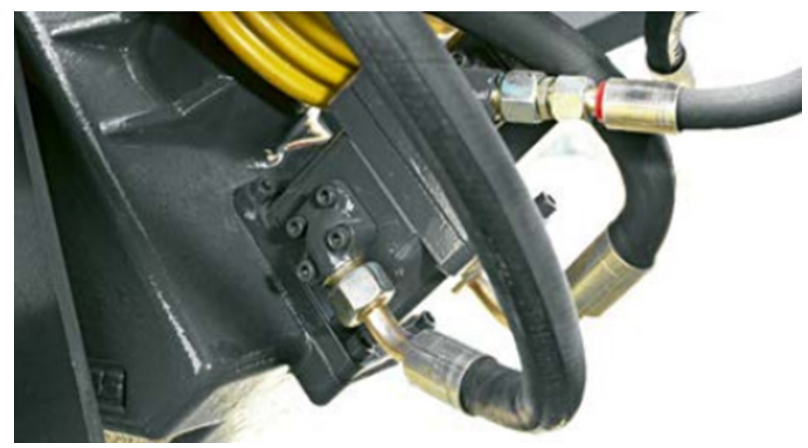

Figure 4: Two oil pumps supply the input gearbox and the TURBO FAN knot cleaning system with hydraulic oil. [14]

Fires arising from agricultural machinery occur mainly in the engine compartment. The consequence, especially on the damaged construction of the machine, often exceeds the value of the machine. Increased requirements to reduce noise and exhaust emissions are the main reasons for greater insulation and enclosure of the engine compartment, increased fuel pressure and thus an increase in engine compartment temperature.

The fire in the engine compartment spreads often and very quickly and intensively, so it cannot be extinguished with a fire extinguisher. Vehicles and equipment in agriculture, such as harvesters, tractors, loaders, etc. are high power machines that work at a constant load. An increasing number of more powerful electrical and hydraulic equipment pose an increased risk, and it is therefore possible to speak of these machines as potentially dangerous sources. [15-16]

If the engine fire start, the whole machine will burn during 20 minutes. Due to the nature of the work area, it can quickly fall victim to a fire, completely isolating the burning vehicle and its operator.
The FOGMAKER system ${ }^{\mathrm{TM}}$ is an automated closed system that can be operated by direct human intervention and without power supply. On the principle of water mist, the fire in the engine compartment of the machine is extinguished. FOGMAKER тм may consist of one, two or three fire extinguishing bottles. The construction allows full use of the content of the extinguishing mixture and thus emptying of the entire extinguishing cylinder. This is a positive advantage because the extinguishing roller can be placed vertically or horizontally in confined spaces. [17-18]

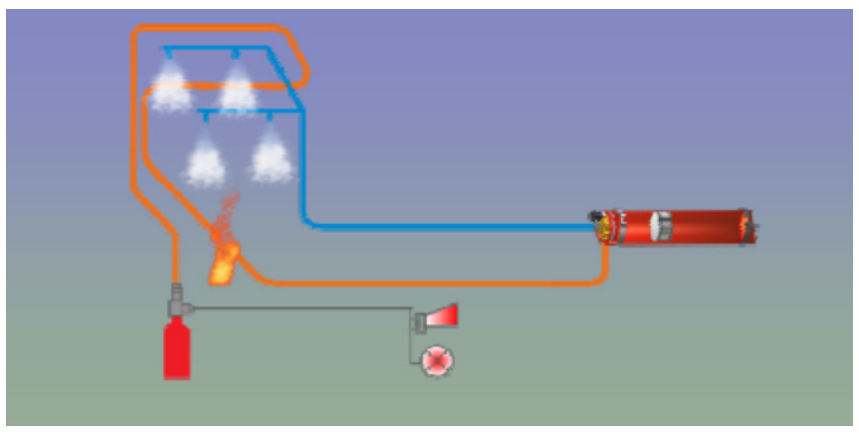

Figure 5: Hydro-pneumatic detection and activation [18]

Detection and activation of the system is performed hydropneumatically.

When a fire occurs, the detection hoses expand / burst with pressure and pressure drop, activating the valve on the extinguishing pressure cylinder. The pressure gauge, which is located on the detection cylinder, then alerts you with light and sound signals.

This power-independent system has an extraordinary cooling effect of $-500^{\circ} \mathrm{C}$ in less than 3 seconds. Water high-pressure mist with a pressure of 100 bar and special nozzles turn water into microdroplets with a diameter of $50 \mu \mathrm{m}$. The volume of 1 drop with a diameter of $1 \mathrm{~mm}$ is sufficient to create 8,000 drops of water mist. Water with a volume of 1 liter absorbs 540,000 calories during evaporation, which gives the extinguishing a completely unique effect. Cooling contributes to rapid extinguishing and thus reduces the risk of re-ignition [19-20].

\section{Discussion}

The result of the analysis was a finding that the cause of the fire is the environment, i.e. the high ambient temperature. The critical element in hay baling processing system is the working environment. Although the primary cause of the fire was a damaged bearing, the high ambient temperature and the presence of hay in the working environment caused an adverse event, i.e. fire. The risk level of the working environment was estimated at the value 1.6 from the interval $\langle 1 ; 2\rangle$. The resulting risk level 5.78 was low due to rapid human intervention. The acceptance limit in this method is set at the value 15 . Based on the results, the technical measures were proposed to the operator. There was determined in this article that the maintenance of the machine is important for protection against the agricultural fires, where the human factor plays an important role in the man - machine environment system. As a damaged bearing or electrical installation contributes significantly to a fire in agriculture, maintenance is absolutely necessary in preventing of fires. 


\section{Conclusion}

It can be stated that a damaged bearing, as stated for presses, plays a major role in the fires of agricultural machinery. For tractors, trucks, the main initiator is an electrical short or faults in the electrical installation. In the case of machines intended for harvesting such as a combine harvester or forage harvester, a damaged bearing or electrical installation contributes significantly to a fire. After the risk analysis with a comprehensive method, satisfactory results were obtained, but this does not mean that there is no danger. The proposed measures to improve the situation are feasible, but nowadays smaller companies cannot afford it. Companies with better financial possibilities hire a special service for machines [21-22].

After the service period, maintenance is performed in-house. Today's companies try to have as little as possible, there are 1 maintenance person on about 10 machines [23-24]. Under the pressure of time, maintenance workers carry out repairs to such an extent that the machine is functional-mobile, but safety is significantly neglected. Today's generation of tractor drivers and engineers also neglects the basic maintenance of machines such as bearing lubrication or engine oil change. Some companies motivate their employees by being paid for maintenance. Machines and systems can be improved from a safety point of view, but the human factor plays the biggest role. Fighting fires in agriculture are liquidated according to the methodological sheets of the Fire and Rescue Service.

\section{Conflict of Interest}

The authors declare no conflict of interest.

\section{Acknowledgment}

APVV 15-0351 Development and application of risk management models in the conditions of technological systems in accordance with the strategy Industry 4.0 and VEGA1/0121/18 Development of methods for implementation and verification of a comprehensive security solution in Smart Factory as part of the Industry 4.0 Strategy.

\section{References}

[1] C. Y. Chen, Y.C. Ling, J. T. Wang, H.Y. Chen, "SIMS depth profiling analysis of electrical arc residues in fire investigation", Applied Surface Science, New York, 2003, https://doi.org/10.1016/S0169-4332(02)00817-6

[2] M. P. Filippakou, C.G. Karagiannopoulos, D.P. Agoris, P.D. Bourkas, "Electrical contact overheating under short-circuit currents" 2001 Electric power systems research. https://doi.org/10.1016/S0378- 7796(01)00081-5

[3] M. Balara, D. Dupláková, D. Matisková, "Application of a signal averaging device in robotics" In: Measurement., 115, 125-132, 2018, https://apps.webofknowledge.com/full_record.do?product=WOS\&search_m ode $=$ GeneralSearch\&qid $=1 \& \mathrm{SID}=\mathrm{C} 2 \overline{\mathrm{GBN}} \ldots$. https://doi.org/10.1016/j.measurement.2017.10.037

[4] D. Matisková, L. Ambiško, "Optimization of cutting conditions and improvement of production in economic terms", TEM Journal., 6 (3), 584590. 2017. ISSN 2217-8309

[5] V. Shah, D. Twidwell, C.L. Wonkka, M.T. Sindelar, J.R. Weir. "First Approximations of Prescribed Fire Risks Relative to Other Management Techniques Used on Private Lands". PLoS ONE 2015

[6] P. J. Val-Aguasca, M. Videgain-Marco, P. Martín-Ramos, M. Vidal-Cortés, A. Boné-Garasa, F. Javier García-Ramos. "Fire Risks Associated with Combine Harvesters: Analysis of Machinery Critical Points", Agronomy 2019, 9, 877, https://doi.org/10.3390/agronomy9120877

[7] I. Hadade, T. M. Jones, F. Wang, L. di Mare, "Software Prefetching for Unstructured Mesh Applications" in 2018 IEEE/ACM 8th Workshop on
Irregular Applications: Architectures and Algorithms (IA3), Dallas, TX, USA, 2018. https://doi.org/10.1109/IA3.2018.00009

[8] J. Shutske, W.E. Field. "An Integrated Loss Control Strategy for Grain Combine Fires". In 1988 International Winter Meeting of the American Society of Agricultural Engineers; American Society of Agricultural Engineers: Chicago, IL, USA, 2014; p. 17.

[9] H. Lihua, "Analysis of Fuel Cell Generation System Application," Ph.D Thesis, Chongqing University, 2005.

[10] Agroinform.hu, Erre vigyázzon bálázáskor, hogy ne gyulladjon ki a gépe, [cit.2018-4-1], https://www.agroinform.hu/gepeszet/erre-vigyazzunkbalazaskor-23427

[11] Agroforum.hu, Ezért gyulladnak ki a bálázók és a kombájnok - Túzvédelmi tanácsok az aratás kezdetére, [cit. 2018-4-1], https://agroforum.hu/agrarhirek/gepinfo/ezert-gyulladnak-ki-a-balazok-es-akombajnok-tuzvedelmi-tanacsok-az-aratas-kezdetere/

[12] Magro.hu, Sok bálázó ég ki munka közben - erre figyeljen Ön is!, [cit. 20184-1],https://www.magro.hu/agrarhirek/szines/sok-balazo-eg-ki-munkakozben-erre-figyeljen/

[13] Agrofarmelectro.com, Csapágy hőfok figyelö, [cit. 2018-4-1], https://www.agroinform.hu/gepeszet/automata-tuzvedelem-amezogazdasagban-12305,

[14] Tiszacsege.hu, Aratás előtti gépszemle, [cit.2018-4-1], http://tiszacsege.hu/wp-ontent/uploads/2014/07/betakaritas tuzvedelem.pdf

[15] Agroinform.hu, Automata tüzvédelem a mezőgazdaságban, [cit. 2018-42],:https://www.agroinform.hu/gepeszet/elozzuk-meg-a-kombajntuzet33150-001

[16] Fogmaker.com, R107, [cit. 2018-4-2], http://fogmaker.com/r107/

[17] Jandjpsv.eu, Meghódította a világot 6 kontinensen több mint 30 országban,[cit.2018-4-2],http://jandjpsv.eu/wpcontent/uploads/sajto/Florian-exPress-2013-oktober.pdf

[18] Enatruck.cz, Fogmaker - unikátní hasicí systém, [cit. 2018-4-2], https://www.enatruck.cz/enatruck-cz/eshop/14-1-Signalizacni-a-hasicisystemy/-4-/5/147-Fogmaker-unikatni-hasici-system

[19] Internal documents of the company, consultation with the security technician and mechanizer of the company, 2015.

[20] Maintenance in Agriculture - A Safety and Health Guide, European Agency for Safety and Health at Work, ISBN 978-92-9191-667-2 https://osha.europa.eu/en/publications/reports/maintenance-in-agriculture-asafety-and-health-guide, 2011.

[21] G.R. Quick. "An Investigation into Combine Harvester Fires"; Grains Research and Development Corporation: Canberra, Australia, 2010.

[22] K. Neubauer, Stroje pro rostlinnou výrobu, (Machines for Agricultural Production), Státní zemědělské nakladatelství, Praha, ISBN 80-209-0075-6, 1989.

[23] J. Sinay, M. Oravec, H. Pačaiová. "Risk assessment methods". Košice: TU, 2001.

[24] T. Henschel, Erfolgreiches Risikomanagement im Mittelstand. Strategien zur Unternehmenssicherung, Erich Schmidt Verlag, Berlin, ISBN 9783503 $116485,2010$. 